\title{
IMPLIKASI YURIDIS POST MERGER NOTIFICATION OLEH PELAKU USAHA DI INDONESIA
}

\author{
Suwinto Johan \\ Management Study Program, Faculty of Business, President University \\ suwintojohan@gmail.com
}

Submitted: 2020-04-04 ;Reviewed: 2020-10-23; Accepted: 2020-11-20

\begin{abstract}
Merger, consolidation, and acquisition of a company are normal activities for businessmen. These activities aims to maximize the value of company to shareholders. The implementation of merger, consolidation, and acquisition have the effect of creating a dominant position and monopolic practices, so those activities requires approval of a commission of business competition monitor. However, is the submission of approval done before or after the transaction made? Based on Undang-Undang Dasar No. 5 Tahun 1999, reporting has to do after transaction made according to criterias estabilished by government regulations. This research use the normative juridical method, case approach and comparative approach. This research aims to show the effects of current post merger notification effect to the business in Indonesia. This research shows the effects of reporting after the transaction made. Comparative approach comparing lex in several countries. This research concludes that pre-notification to KPPU must be made for transactions of a certain value, so as not to cause the effects of uncertainty and high transaction costs.
\end{abstract}

Keywords: Anti-trust; post-merger notification; pre-merger notification.

\section{PENDAHULUAN}

Tujuan berdirinya sebuah badan usaha adalah untuk memaksimalkan nilai perusahaan. Seorang investor akan investasi pada sebuah perusahaan, jika perusahaan tersebut mampu memberikan pengembalian yang lebih tinggi atau sama dengan yang diinginkan. Pengembalian ini dikenal dengan istilah return. Return sebuah investasi (saham) meliputi dividend dan capital gain. 
Untuk mencapai nilai perusahaan yang maksimal, salah satu strategi adalah dengan melakukan pertumbuhan secara un-organik. Strategi un-organik yang dipergunakan adalah dengan melakukan merger dan akuisisi. Perusahaan akan melakukan penggabungan atau peleburan dengan perusahaan sejenis untuk meningkatkan efisiensi dan kemampuan produksi yang lebih baik. Penggabungan perusahaan sejenis akan menurunkan biaya produksi baik biaya produksi langsung maupun bahan baku. Penggabungan jenis bertujuan untuk mencapai transaction cost economies.

Sedangkan penggabungan atau peleburan dengan perusahaan yang berada di tingkat sumber daya baik sumber daya bahan baku maupun sumber daya lainnya disebut resources driven theory. Sedangkan penggabungan dengan perusahaan yang menjadi pembeli maupun yang memiliki pasar, bertujuan untuk mencapai biaya distribusi yang lebih efisiensi dalam value chain, disebut market driven theory. Dengan market driven theory, perusahaan akan mengurangi persaingan di dalam industri dimana saat ini berada dan meningkatkan hambatan masuk bagi pelaku usaha baru. Dengan menggabungkan perusahaan sejenis maka akan meningkatkan kemampuan dalam kompetisi (economics of scale - economies of scope) dan memiliki pangsa pasar yang lebih besar.

Dengan penggabungan atau peleburan jenis ini, maka kekuatan pemasok menjadi tidak signifikan. Sehingga perusahaan akan memiliki kemampuan dalam melakukan negosiasi dengan pemasok bahan. Menurut teori Michael Porter, maka perusahaan perlu melakukan hal-hal agar kekuatan konsumen dan pemasok menjadi tidak signifikan. Selain itu, perusahaan juga perlu meningkatkan hambatan masuknya pelaku baru dan berkurangnya barang sejenis yang memiliki kemampuan subsidi.

Perusahaan dapat melakukan penggabungan atau peleburan dengan perusahaan pemasok untuk mengamankan pemasokan sumber bahan. Dengan penggabungan atau peleburan ini perusahaan akan memiliki nilai kompetitif dengan penggabungan sumber daya. Sehingga perusahaan lain akan mengalami kesulitan untuk berkompetisi, sehingga perusahaan ini akan memiliki keunggulan. Dengan keunggulan ini, maka perusahaan akan memperoleh keuntungan yang lebih dibandingkan perusahaan sejenis. Yang termasuk dalam sumber daya utama adalah yakni sumber daya alam, sumber daya fisik, sumber daya manusia, dan sumber daya organisasi. Penggabungan atau peleburan jenis ini disebut penggabungan atau peleburan vertikal. ${ }^{1}$ Sebuah perusahaan akan berhasil jika telah melakukan identifikasi terhadap sumber daya organisasi yang diperlukan. ${ }^{2}$ Penguasaan sumber daya meliputi sumber daya manusia dan sumber daya bahan baku. Sehingga untuk berhasil, maka perusahaan perlu menguasai sumber dayanya.

Perusahaan yang memiliki skala yang lebih besar, maka akan terciptanya efisiensi. Efisiensi meliputi efisiensi biaya (economies of scale) maupun efisiensi dari jenis produk yang dihasilkan (economies of scope). Dengan penggabungan atau peleburan perusahaan

\footnotetext{
${ }^{1}$ Suwinto Johan, "Implementasi Strategi Bisnis dan Korporasi Melalui Merger dan Akuisisi”, Ultima Management, Vol. 3 No. 1, 2011, hlm. 68.

${ }^{2}$ Irina V. Kozlenkova, Stephen A. Samaha dan Robert W. Palmaties, "Resources-based Theory in Marketing”, Journal of the Academy of Marketing Science, 2013. DOI: 10.1007/s11747-013-0336-7
} 
sejenis, maka perusahaan akan menjadi lebih kompetitif dalam bersaing, sehingga menghasilkan biaya produksi yang lebih rendah dengan jumlah produksi yang banyak maupun jenis produk yang dihasilkan lebih bervariasi. Penggabungan atau peleburan jenis ini disebut penggabungan atau peleburan horizontal.

Dengan demikian, penggabungan dan peleburan akan perusahaan akan meningkatkan kemampuan perusahaan menjadi lebih kompetitif dengan penggabungan sumber daya yang dimiliki oleh kedua perusahaan. Dengan kemampuan yang lebih kompetitif ini, pelaku usaha dapat menguasai pangsa pasar yang lebih besar. Dengan pangsa pasar yang lebih besar, maka perusahaan atau pelaku usaha dapat menjadi posisi dominan. Posisi dominan ini akan memiliki pengaruh pada kondisi persaingan pada pasar. Sehingga pengendalian merger harus dianggap serius untuk menghindari kerugian yang tidak perlu dari kegagalan untuk mematuhi rezim pengendalian merger. ${ }^{3}$

Perusahaan pembiayaan yang diakuisisi oleh pemegang saham asing akan menjadi lebih efisien, lebih besar untuk ukuran dan pertumbuhan aset. Selama 2 dekade terakhir, pertumbuhan penanaman modal asing pada negara berkembang telah bertumbuh pesat. Mayoritas penanaman modal asing adalah melalui transaksi merger dan akusisi. ${ }^{4}$ Dengan ukuran aset yang lebih besar dan pertumbuhan aset yang lebih besar, maka perusahaan yang dimiliki oleh investor asing berpotensi memiliki posisi dominan. ${ }^{5}$ Perusahaan yang melakukan merger dan akuisisi memiliki perbaikan kinerja terutama pada segi rasio lancar, rasio profitabilitas dan rasio perbandingan utang terhadap modal pada tahun 2013$2015 .^{6}$

Di lain pihak, perusahaan yang melakukan merger dan akuisisi tidak ditemukan adanya perbaikan kinerja keuangan setelah 2 tahun. ${ }^{7}$ Secara empiris, merger dan akuisisi tidak dapat menjadi salah satu cara perusahaan untuk memperoleh pertumbuhan profitabilitas ataupun perbaikan likuiditas jangka pendek. ${ }^{8}$ Kinerja perusahaan tidak mengalami perbedaan yang signifikan pada periode perbandingan tahun 2010-2012 untuk rasio keuangan seperti current ratio, total asset turnonver, fixed aset turnover, debt to

\footnotetext{
3 A.M. Tri Anggarini, dan Farid F. Nasution, "Pengendalian Merger Berdasarkan Hukum Persaingan (Merger Control Based on Competitiion Law)", Jurnal Legislasi Indonesia, Vol. 10 No. 2, 2013, hlm.191. ${ }^{4}$ Ping Deng dan Monica Yang, "Cross-Border Mergers and Acquisition by Emerging Market Firms: A Comparative Investigation", International Business Review, Vol. 24 No. 1, 2015, p. 157. http://dx.doi.org/10.1016/j.ibusrev.2014.07.005

5 Suwinto Johan, Hermanto Siregar, Perdana Wahyu Santoso, dan Tubagus Nur Ahmad Maulana, "Do Foreign Firms Bring Value to Emerging Country?”, Journal of Technology Management, Vol. 11 No. 3 , 2012, p. 239.

${ }^{6}$ Munawir Nasir dan Tiara Morina, “Analisis Perbandingan Kinerja Keuangan Pada Peruahaan Sebelum dan Sesudah Merger dan Akuisisi (Studi Perusahaan Yang Melakukan Merger dan Akuisisi Yang Terdaftar di BEI 2013-2015)", Jurnal Economic Resources, Vol. 1 No. 1, 2018, hlm. 71.

7 Rekha Resmilia, Arief Tri Hardianto, danAgung Fajar Ilmiyono, "Pengaruh Merger dan Akuisisi Terhadap Kinerja Keuangan Perusahaan Manufaktur Go Public Yang Terdaftar di BEI Periode 2012-2014”, Jurnal Onlne Mahasiswa (JOM) Bidang Akuntansi, Vol. 5 No. 5, 2018.

8 Mardianto dan Natalis Christian Edi, "Dampak Merger dan Akuisisi Terhadap Kinerja Keuangan Perusahaan", Jurnal Benefita, Vol. 3 No. 1, 2018, hlm. 44.
} 
equity ratio, net profit margin dan rasio profitabilitas lainnya. ${ }^{9}$ Merger antara perusahaan dalam satu industri akan memiliki efek kenaikan harga produk dan memiliki efek unilateral. ${ }^{10}$ Sehingga dapat disimpulkan bahwa, efek dominasi pasar akan terjadi dan profitabilitas akan muncul dalam jangka panjang.

Berdasarkan Pasal 28 Undang Undang No. 5 Tahun 1999, dimana disebutkan bahwa pelaku usaha dilarang melakukan penggabungan atau peleburan badan usaha yang dapat mengakibatkan terjadinya praktek monopoli dan atau persaingan usaha tidak sehat. Dan pelaku usaha dilarang melakukan pengambilalihan saham perusahaan lain apabila tindakan tersebut dapat mengakibatkan terjadinya praktek monopoli dan atau persaingan usaha tidak sehat. Transaksi penggabungan badan usaha, peleburan badan usaha, atau pengambilalihan saham akan menimbulkan tercapainnya potensi persaingan usaha tidak sehat dengan penguasaan sumber daya dan integrasi usaha.

Sedangkan pada pasal 29 UU No. 5 Tahun 1999, disebutkan bahwa penggabungan atau peleburan badan usaha, atau pengambilalihan saham sebagaimana dimaksud dalam Pasal 28 yang berakibat nilai aset dan atau nilai penjualannya melebihi jumlah tertentu, wajib diberitahukan kepada Komisi Pemantau Persaingan Usaha (KPPU), selambatlambatnya 30 (tiga puluh) hari sejak tanggal penggabungan, peleburan, atau pengambilalihan tersebut. Kontrol terhadap merger merupakan aspek yang penting dalam regim kompetisi bisnis. Merger memiliki implikasi terhadap timbulnya praktek monopoli dan persaingan yang tidak sehat. ${ }^{11}$

Akan tetapi dalam beberapa pelaporan, telah melampaui kewajiban selambatlambatnya 30 hari kerja kalender. Transaksi pengambilalihan oleh PT. Nippon Indosari Corpindo, tbk terhadap PT. Prima Top Boga pada tanggal 24 Januari 2018, seharusnya dilaporkan selambat-lambatnya pada tanggal 23 Maret 2018, akan tetapi pelaporan baru dilakukan pada tanggal 29 Maret 2018. ${ }^{12}$

Pelaporan yang dilakukan adalah pelaporan setelah transaksi dilakukan dengan jangka waktu 30 hari sejak terjadinya penggabungan, peleburan atau pengambilalihan. Akan tetapi hal ini mejadi belum efektif karena KPPU memiliki otoritas untuk membatalkannnya sesuai dengan Pasal 47 berdasarkan UU No. 5 / 1999. Dalam pasal tersebut tertulis, KPPU dapat menetapkan pembatalan atas penggabungan atau peleburan badan usaha dan pengambilalihan saham; dan atau penetapan pembayaran ganti rugi akibat transaksinya; dan atau pengenaan denda serendah-rendahnya Rp 1.000.000.000,00

\footnotetext{
${ }^{9}$ Prisya Esterlina dan Nila Nuzula Firdausi, “Analisis Kinerja Keuangan Perusahaan Sebelum dan Sesudah Merger dan Akuisisi”, Jurnal Administrasi Bisnis (JAB), Vol. 47 No. 2, 2017, hlm. 39.

${ }^{10}$ Joseph Farrell dan Carl Shapiro, "Antitrust Evaluation of Horizontal Mergers: An Ecoomic Alternative to Market Definition", The B.E. Journal of Theoretical Economics, Vol. 10 No. 1, 2010, Article 9.

${ }^{11}$ A. M. T. Anggraini, "Merger Control Based On Anti Monopoly Law in Indonesia: Comparison in Some Asean Member States". Forum Dosen Persaingan Usaha, 2017, p. 45. https://doi.org/10.1017/CBO9781107415324.004

12 Suradiyanto dan Dinny Wirawan Pratiwie, "Analisis Yuridis Pengambialihan Saham PT. Prima Top Boga Oleh PT. Nippon Indosari Corpindo, Tbk Dari Perpektif Undang Undang Nomor 5 Tahun 1999 (Studi Kasus Putusan Komisi Pengawas Persaingan Usaha Nomor: 07/KPPU-M/2018)”, Jurnal Ilmiah Hukum, Vol. 11 No. 2, 2019, hlm. 178.
} 
(satu miliar rupiah) dan setinggi-tingginya Rp 25.000.000.000,00 (dua puluh lima miliar rupiah).

Kewajiban pelaporan ini dibatasi dengan nilai aset dan/atau nilai penjualannya melebihi jumlah tertentu wajib diberitahukan secara tertulis kepada KPPU paling lama 30 (tiga puluh) hari kerja sejak tanggal telah berlaku efektif secara yuridis penggabungan badan usaha, peleburan badan usaha, atau pengambilalihan saham perusahaan. Sedangkan jumlah tertentu terdiri atas: a. nilai aset sebesar Rp2.500.000.000.000,00 (dua triliun lima ratus miliar rupiah); dan/atau b. nilai penjualan sebesar Rp5.000.000.000.000,00 (lima triliun rupiah). Bagi pelaku usaha di bidang perbankan kewajiban menyampaikan pemberitahuan secara tertulis berlaku jika nilai aset melebihi Rp20.000.000.000.000,00 (dua puluh triliun rupiah).

Sedangkan berdasarkan Peraturan Pemerintah Pasal 2 No. 57 Tahun 2010, pelaku usaha dilarang melakukan penggabungan badan usaha, peleburan badan usaha, atau pengambilalihan saham perusahaan lain yang dapat mengakibatkan terjadinya praktik monopoli dan/atau persaingan usaha tidak sehat. Dalam hal praktik monopoli dan/atau persaingan usaha tidak sehat sebagaimana dimaksud terjadi jika badan usaha hasil penggabungan, badan usaha hasil peleburan, atau pelaku usaha yang melakukan pengambilalihan saham perusahaan lain diduga melakukan perjanjian yang dilarang; kegiatan yang dilarang; dan/atau penyalahgunaan posisi dominan.

Penggabungan badan usaha, peleburan badan usaha, atau pengambilalihan saham akan menimbulkan potensi menjadi posisi dominan. Karena tujuan daripada penggabungan, peleburan dan pengambilalihan adalah mencapai sinergi dan penguasaan sumber daya. Disamping, tujuannya adalah mencapai nilai kompetitif dibandingkan pelaku usaha sejenis.

Post-notification menimbulkan tidak efisien dan tidak efektif dalam transaksi merger dan menimbulkan ketidakpastian bagi pelaku usaha. Anna Maria Tri Anggarini ${ }^{13}$ menyimpulkan bahwa pelaku usaha cenderung untuk melakukan post-merger notification, dikarenakan jika KPPU tidak menolak transaksi penggabungan, peleburan dan pengambilalihan, maka proses pemeriksaan lebih lanjut tidak diperlukan. Jika dilakukan pre-merger notification, maka pelaku usaha akan melalui proses pemeriksaan terlebih dahulu. ${ }^{14}$

Pre-merger notification sangat penting. Penelitian ini mengusulkan diperlukannya pembatasan nilai transaksi untuk diberlakukannya pre-merger notification. ${ }^{15}$ Merger yang wajib memberitahukan kepada Department of Justice (DoJ) and the Federal Trade Commission (FTC) di Amerika. Sebelum adanya persetujuan dari DOJ dan FTC, maka

\footnotetext{
${ }^{13}$ A. M. T. Anggraini, "Mandatory Post Merger Notification Under The Merger Review Regulation In Indonesia". Celebrating Diversity: 10 years of ASLI, 10th Asian Law Institute Conference, 2013, p. 1.

${ }^{14}$ Fahamsyah Ermanto dan Suri Fadhillah Atika, "Post-Notification Arrangements in Merging Business Entities (Mergers) as an Effort to Prevent Unfair Business Competition”. Lentera Hukum, Vol. 6 Issue 2, 2019 , p. 213.

15 Buccirossi, P., Cervone, R., Riviera, C., dan Regime, I. M., "Optimal Pre-Merger Notification Thresholds: a Contribution To the Italian Debate". Italian Antitrust Review, 3, 2014, p.166, https://doi.org/10.12870/iar-11061.
} 
transaksi tidak boleh dilakukan. Kedua komisi ini akan melakukan pengujian terhadap hasil penggabungan ini dengan persaingan usaha tidak sehat berdasarkan kriteria HartScott-Rodino (HSR). ${ }^{16}$

Kekurangan dalam pemberitahuan akan menimbulkan masalah problematik dalam merger dan memiliki efek negative pada pelaku pasar. Selain itu, kebebasan pelaporan akan menimbulkan efek negative terhadap pasar konsumen akibat daripada kegiatan merger. ${ }^{17}$ Kebebasan pelaporan merger akan mencapai hasil yang sama dengan pelaporan yang wajib dengan biaya yang sama bagi pelaku usaha dan regulator. ${ }^{18}$

Indonesia menjadi satu-satunya negara di ASEAN yang telah memiliki peraturan persaingan usaha, yang menganut post- merger notification and voluntary pre-merger notification; sedangkan negara ASEAN lainnya mengadopsi pre-merger notification. ${ }^{19}$ Sehingga pentingnya pencegahan terhadap kemungkinan terjadinya praktik monopoli dan persaingan usaha tidak sehat diketahui sejak dini dan dapat dicegah, jika notifikasi merger dilakukan sebelum aksi korporasi dilakukan atau disebut dengan pra-notifikasi. ${ }^{20}$ Kewajiban notifikasi pasca transaksi 3P (penggabungan, peleburan, pengambilalihan) tidak cukup efektif dalam rangka mencegah persaingan usaha tidak sehat di Indonesia, sehingga harus diubah menjadi notifikasi pra transaksi $3 \mathrm{P}^{21}$

Oleh karena itu, diperlukan perubahan rezim menjadi pra-notifikasi daripada postnotifikasi merger. Sehingga Komisi Pemantuan Persaingan Usaha (KPPU) mampu menjadi pelindung utama akan terciptanya keadaan pasa yang adil dan kondusif. ${ }^{22}$

\section{I.Metode Penelitian}

Penelitian ini mempergunakna metode yuridis normatif dan metode perbandingan hukum. Metode perbandingan hukum dengan mempelajari beberapa transaksi dilakukan di Indonesia maupun lokasi lain yang berhubungkan dengan notifikasi merger dan akuisisi. Tujuan mempelajarai transaksi-transaksi untuk mengetahui sistem pelaporan yang ada berdasarkan peraturan perundang-undangan.

\footnotetext{
${ }^{16}$ Menesh S. Patel, Merger Breakups, December 6, 2019

${ }^{17}$ International Chamber of Commerce. (2015). ICC Recommendations on Pre-Merger Notification Regimes. Retrieved from http://www.icc.nl/docman-standpunten/docman-commissies/docmancommisies-mededinging/69-icc-recommendations-on-pre-merger-notification-regimes/file

${ }^{18}$ Chongwoo, C., dan Shekhar, C. (2009). "Compulsory or Voluntary Pre-merger Notification? Theory and Some Evidence Compulsory or Voluntary Pre-merger Notification? Theory and Some Evidence". Munich Personal RePEc Archive, (13450), 39.

${ }^{19}$ A.M.T. Anggarini, "Merger Control Based On Anti Monopoly Law in Indonesia: Comparison in Some Asean Member States". Forum Dosen Persaingan Usaha, 2017, p. 45. https://doi.org/10.1017/CBO9781107415324.004

${ }^{20}$ Hottua Manalu, "Notifikasi Aksi Korporasi Sebagai Instrumen Hukum Pencegah Praktik Monopoli dan Persaingan Usaha Tidak Sehat", Undang: Jurnal Hukum, Vol 2 No.1, 2019, p. 33. DOI: 10.22437/ujh.2.1.33-67

21 Xavier Nugraha, Rizki Istighfariana Achmadi, Nina Ammelia Novita Sari, "Urgensi Notifikasi Pratransaksi 3P (Penggabungan, Peleburan, Pengambilalihan) Upaya Preventif Persaingan Usaha Tidak Sehat", Legistatif, Vol. 2 No. 2, 2019, p. 84.

${ }^{22}$ Farid Ibrahim Suhandi, "Kebijakan Pre-Merger Notification Badan Usaha Sebagai Penegakan Hukum di Era Revolusi Industri 4.0”, Lex Scientia Law Review, Vol. 3 No. 2, 2019, p. 129.
} 
Pada penelitian ini mempergunakan bahan atau data primer dan bahan atau data sekunder. Data primer merupakan bahan atau data yang diperoleh langsung dari lapangan sebagai sumber utama. Sedangkan bahan sekunder merupakan bahan kepustakaan berupa bahan hukum primer, bahan hukum sekunduer dan bahan hukum tertier. ${ }^{\mathbf{2 3}}$

Analisis data dilakukan secara kualitatif, yaitu analisa yang bertujuan untuk menganalisis suatu keadaan atau status fenomena dengan kata-kata atau kalimat, kemudian dipisahkan sesuai tujuan penelitian untuk memgambil kesimpulan. Kesimpulan ditarik secara induktif yaitu dengan menjabarkan segala hal secara mendetail dan diakhir dengan data atau fakta umum.

\section{PEMBAHASAN}

Berdasarkan Peraturan Pemerintah Pasal 3 No. 57 Tahun 2010, KPPU memiliki otoritas untuk membatalkan transaksi penggabungan badan usaha, peleburan badan usaha, atau pengambilalihan saham perusahaan yang telah berlaku efektif, jika diduga terjadinya praktik monopoli dan/atau persaingan usaha tidak sehat. Penilaian dilakukan dengan menggunakan analisis: konsentrasi pasar; hambatan masuk pasar; potensi perilaku anti persaingan; efisiensi; dan/atau kepailitan. Pembatalan ini akan mengakibatkan timbulnya biaya yang harus ditanggung oleh pihak penjual dan pembeli badan usaha. Pembatalan ini juga tidak dibatasin jumlah waktu yang diperlukan untuk menganalisis terhadap badan usaha yang digabungkan.

Pelaporan setelah transaksi (post-merger notification), akan menimbulkan kepastian kepada para pihak yang terlibat. Pihak-pihak ini diantaranya:

1. Pemegang saham selaku penjual

2. Pemegang saham minoritas akan mengalami ketidakpastian terhadap siapa yang menjadi penanggungjawab perusahaan sehubungan dengan perubahan pemegang saham

3. Otoritas terkait seperti pasar modal, otoritas jasa keuangan

4. Profesi pendukung transaksi termasuk notaris

5. Badan-badan pemerintahan seperti perpajakan yang dikenakan dan yang harus dibayar Departemen Hukum dan HAM yang menerima pendaftaran perubahan anggaran dasar.

6. Manajemen yang akan diangkat melalui keputusan RUPS sejalan dengan Undang Undang Perseroan Terbatas No. 40 Tahun 2007.

7. Karyawan yang memerlukan perbaharuan kontrak kerja dengan manajemen baru yang ditunjuk oleh pemegang saham baru. Hal ini sejalan dengan Undang Undang No. 13 Tahun 2003.

\footnotetext{
${ }^{23}$ Lie, Gunardi. Saly, Jeane Nelje. Gunadi, Ariawan. Tirayo, "Adriel Michael. Problematika UU No. 37 Tahun 2004 Tentang Kepailitan dan PKPU Terhadap Bank Sebagai Kreditor Separatis", Jurnal Bakti Masyarakat Indonesia, Vol 2 No. 2, November 2019.
} 
Beberapa asas hukum yang memiliki keterkatian dengan Undang Undang Anti Monopoli dan Persaingan Usaha yakni ${ }^{24}$

1. Lex Superior Derogat Legi Inferiori, menurut asas ini, apabila terjadi pertentangan antara peraturan perundang-undangan yang secara hierarkis leih rendah dengan yang lebih tinggi, maka peraturan perundang-undangan yang hierarkinya lebih rendah tersebut disisihkan.

2. Lex Specialis Legi Inferiori, menurut asas ini, jika ada dua perundangundangan yang dibuat oleh suatu lembaga yang sama. Yang satu diperintahkan oleh undang-undang sedangkan yang lainnya diperintahkan oleh peraturan pemerintah. Hukum yang kedudukannya lebih tinggi menghapus hukum yang ada di bawahnya, atau dengan kata lain hukum yang lebih rendah tingkatannya harus sesuai dengan ketentuan yang ada di atasnya

3. Lex Posterior Derogate Legi Priori, menurut asas ini, peraturan perundangundangan yang terkemudian menyisihkan peraturan perundang-undangan yang terdahulu.

4. Lex Specialis Derogat Legi Generali. Asas ini merujuk pada dua peraturan perundang-undangan yang secara hiearkis mempunyai kedudukan sama. Akan tetapi, ruang lingkup materi muatan antara kedua peraturan perundangundangan itu tidak sama, yaitu yang satu merupakan pengaturan yang secara khusus dari yang lain.

Berdasarkan asas-asas di atas, maka dapat disimpulkan bahwa post-merger notification KPPU didasarkan pada Undang Undang No. 5 Tahun 1999, dimana:

1. Undang Undang No. 5 Tahun 1999 memiliki kesamaan dengan Undang Undang No. 40 Tahun 2007 mengenai Perseroan Terbatas, dimana berlaku asas Lex Specialis Derogat Legi Generali.

2. Undang Undang No. 5 Tahun 1999 juga memiliki pengaturan khusus mengenai praktek monopoli dan persaingan usaha tidak sehat, maka berlaku asas Lex Specialis Derogat Legi Generali

3. Undang Undang No. 5 Tahun 1999 juga menghapus peraturan perundangundangan sebelumnya, berlaku asas Lex Posterior Derogate Legi Priori.

4. Undang Undang No. 5 Tahun 1999 juga menghapus peraturan perundangundangan dibawahnya, sehingga berlaku Lex Specialis Legi Inferiori.

Sehingga dapat disimpulkan bahwa walaupun peraturan perundang-undangan telah memberikan persetujuan atau telah dipenuhi oleh pelaku usaha untuk penggabungan, peleburan dan pengambilalihan, KPPU tetap memiliki otoritas untuk membatalkannya. Pembatalan ini didasarkan pada analisis KPPU berdasarkan Undang Undang No. 5 Tahun 1999.

\footnotetext{
${ }^{24}$ Peter Mahmud Marzuki, Penelitian Hukum, Prenadamedia Group, Jakarta, 2019
} 
Dialogia luridica: Jurnal Hukum Bisnis dan Investasi

Volume 12 Nomor 1, November 2020

Selama ini, perkara yang diputuskan oleh KPPU masih bersifat keterlambatan dalam pelaporan. Adapun perkara-perkara tersebut dijelaskan pada tabel 1 .

Tabel 1. Putusan Perkara KPPU Terhadap Transaksi Penggabungan, Peleburan dan Pengambilalihan

\begin{tabular}{|c|c|c|c|c|}
\hline No. & Putusan Perkara & Pihak Terlapor & $\begin{array}{l}\text { Dugaan Pelanggaran } \\
\text { Pasal }\end{array}$ & Sanksi \\
\hline 1 & 08/KPPU-M/2012 & $\begin{array}{l}\text { PT. Bumi Kencana Eka } \\
\text { Sejahtera }\end{array}$ & $\begin{array}{llr}\text { Pasal } & 29 & \text { Undang } \\
\text { Undang } & \text { No. 5 Tahun } \\
1999 & & \end{array}$ & Tidak Melanggar \\
\hline 2 & 09/KPPU-M/2012 & $\begin{array}{l}\text { PT. Mitra Pinasthika } \\
\text { Mustika }\end{array}$ & $\begin{array}{llr}\text { Pasal } & 29 & \text { Undang } \\
\text { Undang } & \text { No. 5 Tahun } \\
1999 & & \end{array}$ & $\begin{array}{l}\text { Denda } \\
\text { Rp. 4.600.000.000,- }\end{array}$ \\
\hline 3 & 01/KPPU-M/2014 & $\begin{array}{l}\text { PT. Muarabungo } \\
\text { Plantation }\end{array}$ & $\begin{array}{llr}\text { Pasal } & 29 & \text { Undang } \\
\text { Undang } & \text { No. } 5 & \text { Tahun } \\
1999 & & \end{array}$ & $\begin{array}{l}\text { Denda } \\
\text { Rp. 1.249.000.000,- }\end{array}$ \\
\hline 4 & 02/KPPU-M/2014 & $\begin{array}{l}\text { PT. Balaraja Bisco } \\
\text { Paloma }\end{array}$ & $\begin{array}{llr}\text { Pasal } & 29 & \text { Undang } \\
\text { Undang } & \text { No. } 5 & \text { Tahun } \\
1999 & & \end{array}$ & $\begin{array}{l}\text { Denda } \\
\text { Rp. 5.000.000.000,- }\end{array}$ \\
\hline 5 & 03/KPPU-M/2014 & PT. Dunia Pangan & $\begin{array}{llr}\text { Pasal } & 29 & \text { Undang } \\
\text { Undang } & \text { No. } 5 & \text { Tahun } \\
1999 & & \end{array}$ & $\begin{array}{l}\text { Denda } \\
\text { Rp. 1.000.000.000,- }\end{array}$ \\
\hline 6 & 07/KPPU-M/2014 & PT. Tri Marga Trakindo & $\begin{array}{llr}\text { Pasal } & 29 & \text { Undang } \\
\text { Undang } & \text { No. } 5 & \text { Tahun } \\
1999 & & \\
\end{array}$ & $\begin{array}{l}\text { Denda } \\
\text { Rp. 1.000.000.000,- }\end{array}$ \\
\hline
\end{tabular}

Sumber : KPPU

Dari 6 perkara yang dipilih secara acak dari putusan KPPU, 5 di antaranya adalah pelanggaran pasal 29 Undang Undang No. 5 Tahun 1999. Pihak pengambilalih yang menjadi pihak terlapor. Pihak terlapor dikenai denda atas pelanggaran pasal 29 UU No. 5 / 1999. Denda dikenakan tas dasar hari keterlambatan dalam penyampaian pelaporan kepada KPPU.

Berdasarkan data per tanggal 8 Maret 2020, laporan yang telah disampaikan kepada KPPU sejak 2010 hingga 2019, yang telah diberikan pendapat oleh KPPU sebanyak 100\% hanya dari tahun 2010 hingga 2013. Masih terdapat banyak pelaporan yang KPPU belum memberikan pendapat terhadap transaksi yang dilaporkan.

Dengan mempertimbangkan data-data pelaporan tersebut, maka disimpulkan bahwa transaksi penggabungan, peleburan dan pengambilalihan meningkat dari tahun ke tahun sejak 2010 hingga 2019. Akan tetapi pemberian pendapat oleh KPPU memilki keterlambatan hingga lebih dari 1 tahun. Jumlah Pelaporan yang memerlukan keputusan oleh KPPU dari tahun ke tahun dijelaskan pada tabel 2. 
Tabel 2. Pelaporan yang Telah Disampaikan dan Pelaporan yang Telah Diberikan Pendapat

\begin{tabular}{|c|c|c|c|c|}
\hline No. & Tahun & $\begin{array}{c}\text { Jumlah Laporan / } \\
\text { Transaksi }\end{array}$ & $\begin{array}{c}\text { KPPU telah memberikan } \\
\text { pendapat (dalam transaksi) }\end{array}$ & $\begin{array}{c}\text { \% Pendapat Terhadap } \\
\text { Pelaporan }\end{array}$ \\
\hline 1. & 2019 & 50 & 0 & $0,00 \%$ \\
\hline 2. & 2018 & 74 & 5 & $6,76 \%$ \\
\hline 3. & 2017 & 90 & 63 & $70,00 \%$ \\
\hline 4. & 2016 & 65 & 54 & $83,08 \%$ \\
\hline 5. & 2015 & 51 & 45 & $88,23 \%$ \\
\hline 6. & 2014 & 55 & 52 & $94,55 \%$ \\
\hline 7. & 2013 & 69 & 69 & $100,00 \%$ \\
\hline 8. & 2012 & 36 & 36 & $100,00 \%$ \\
\hline 9. & 2011 & 43 & 43 & $100,00 \%$ \\
\hline 10. & 2010 & 3 & 3 & $100,00 \%$ \\
\hline
\end{tabular}

Sumber : www.kppu.go.id

Keterlambatan ini bisa disebabkan oleh beberapa hal:

1. Kekurangan tenaga di KPPU

2. Pelaporan yang tidak menyerahkan dokumen yang lengkap

\section{Bagaimana implikasi jika setelah post-merger notification dilakukan, dan ditolak oleh KPPU?}

Keputusan KPPU yang tidak meyetujui transaksi peleburan dan penggabungan akan menimbulkan biaya yang tinggi. Remedies dalam bentuk pembatalan atau pengalihan transaksi. Implikasi hal ini akan mempengaruhi:

1. Antara penjual badan usaha dan pembeli badan usaha telah melakukan transaksi dengan melakukan pembayaran lunas. Pengembalian nilai pembelian ini akan memiliki biaya kompensasi terutama biaya bunga. Pengalihan transaksi juga akan menimbulkan biaya tambahan sesuai dengan remedies yang diberikan.

2. Implikasi kepada pihak stakeholders:

a. Karyawan akan memiliki implikasi yang tidak jelas, karena tidak jelasnya pemegang saham baru

b. Pemasok akan juga akan mengalami ketidakjelasan. Pembatalan akan menimbulkan implikasi negative di mata pemasok

c. Pemerintah juga akan kesulitan dalam menentukan pajak transaksi atas penjualan dan pembelian pelaku usaha ini

d. Kreditur juga akan mengalami ketidakpastian terhadap keputusan pembatalan ini.

e. Pihak terkait lainnya, seperti penasehat hukum, notaris, akuntan dan lainnya. Pihak-pihak ini akan mengalami masa tunggu atas transaksi yang dilakukan ini. Jika terjadi pembatalan, maka para pihak akan menerima kompensasi yang lebih kecil dibandingkan dengan jika transaksi jadi dilakukan. 
3. Opportunity Cost. Selama dalam masa tunggu, maka pelaku usaha akan memiliki opportunity cost atau opportunity lost karena masih menunggu kepastian keputusan dari KPPU.

Hal ini sejalan dengan peneltian $\mathrm{Li}$ dan $\mathrm{Hou}^{25}$, yang menyatakan biaya yang harus dikeluarkan dengan kewajiban pelaporan terhadap kegiatan penggabungan dan peleburan badan usaha. Kegiatan menimbulkan biaya yang besar. Biaya-biaya meliputi biaya investigasi, biaya pemberitahuan dan adanya opportunity cost pada waktu investigasi sedang dilakukan. Li dan Hou mengusulkan pelaporan yang tidak wajib atas transaksi penggabungan dan peleburan

Jika keputusan KPPU adalah pengenaan denda, maka hal ini juga akan menimbulkan ketidakjelasan. Denda ini wajib ditanggung oleh siapa:

1. biaya tambahan menjadi kewajiban yang ditanggung oleh pembeli, maka hal ini akan menambah biaya yang harus dikeluarkan.

2. biaya tambahan ditanggung oleh pelaku usaha, maka biaya ini akan menjadi tanggungan pembeli atau penjual?

Sehingga keputusan yang diambil oleh KPPU akan menimbulkan ketidakpastian bagi penjual, pembeli dan pelaku usaha, jika KPPU mengenakan denda administratif maupun pembatalan transaksi.

Tabel 3. Pre Merger Notification dan Post-Merger Notification

\begin{tabular}{|c|c|c|c|}
\hline No. & Keterangan & Kelebihan & Kekurangan \\
\hline 1. & $\begin{array}{l}\text { Pre-Merger } \\
\text { Notification }\end{array}$ & $\begin{array}{l}\text { 1. Memberikan Kepastian Transaksi yang } \\
\text { akan dilakukan } \\
\text { 2. Opportunity cost yang lebih rendah }\end{array}$ & $\begin{array}{l}\text { 1. Potensi transaksi bisa } \\
\text { bocor } \\
\text { 2. Proses yang lebih lama }\end{array}$ \\
\hline 2. & $\begin{array}{l}\text { Post-Merger } \\
\text { Notification }\end{array}$ & $\begin{array}{l}\text { 1. Kerahasiaan transaksi terjamin } \\
\text { 2. Proses transaksi yang lebih cepat antar } \\
\text { pelaku usaha, tetapi perlu waktu } \\
\text { tunggu persetujuan KPPU } \\
\text { 3. Tidak perlu melakukan pembuktian, } \\
\text { jika KPPU menyetujui transaksi. } \\
\text { 4. Tidak semua transaksi perlu pendapat } \\
\text { KPPU }\end{array}$ & $\begin{array}{l}\text { 1. Potensi transaksi bisa } \\
\text { dibatalkan atau dikenal } \\
\text { remedies } \\
\text { 2. } \begin{array}{l}\text { Biaya transaksi yang } \\
\text { tinggi karena } \\
\text { ketidakpastian }\end{array} \\
\text { 3. Waktu tunggu yang lama }\end{array}$ \\
\hline
\end{tabular}

Sumber : Hasil Penelitian

Dengan pre-merger notification, maka pelaku usaha akan memiliki kelebihan dengan memberikan kepastian persetujuan terhadap transaksi yang akan dilakukan sebagaimana dijelaskan pada tabel 3. Hal ini akan menimbulkan biaya yang rendah. Akan Tetapi pre-merger notification akan memiliki risiko transaksi bocor dan proses yang lebih

${ }^{25} \mathrm{Li}$, J., dan Hou, L, "The Compulsory Notification Mechanism under Merger Control in China: Evaluation and Reform". SSRN Electronic Journal, 630, 2019, p. 1. 
lama. KPPU akan memerlukan waktu untuk melakukan penyelidikan transaksi yang akan dilakukan sebelum memberikan pendapat.

Jika post-merger notification dilakukan, maka risiko kerahasiaan transaksi akan bocor, sehingga bisa menimbulkan spekulasi transaksi, jika pelaku usaha merupakan perusahaan terbuka. Kebocoran ini akan mengakibatkan terjadinya insider trading. Jika terjadi insider trading, maka harga transaksi akan berubah karena harga saham akan naik secara signifikan. Dengan post-merger notification, proses transaksi akan berjalan lebih cepat antara para pihak, walaupun tetap harus menunggu persetujuan dari KPPU. Dengan remedies yang diputuskan kemudian hari, maka berpotensi terjadinya ketidakpastian transaksi.

Kekhawatiran akan kebocoran transaksi atau gagalnya transaksi pengambilalihan, merupakan hal yang normatif di Indonesia. Ada beberapa transaksi yang batal dilakukan walaupun sudah diketahui oleh publik. Adapun transaksi-transaksi ini dijelaskan pada tabel 4.

Tabel 4. Transaksi yang Batal

\begin{tabular}{|c|l|l|l|}
\hline No. & \multicolumn{1}{|c|}{ Perusahaan Target } & \multicolumn{1}{|c|}{ Industri } & \multicolumn{1}{|c|}{ Perusahaan Pengambilalih } \\
\hline 1. & Bank Permata & Keuangan & Bank Mandiri \\
\hline 2. & Bank Danamon & Keuangan & Development Bank of Singapore \\
\hline 3. & 7-Eleven & Retail & Charoen Pokphand \\
\hline 4. & Bank Permata & Keuangan & OCBC Bank \\
\hline 5. & Wahana Otto Multiartha & Pembiayaan & Reliance Group \\
\hline 6. & Batavia Air & Penerbangan & Air Asia \\
\hline 7. & Indonesian Tower & Infrastruktur & Telekomunikasi Indonesia \\
\hline
\end{tabular}

Sumber : Hasil Penelitian

Nilai tambah lainnya adalah jika KPPU memberikan pendapat menyetujui transaksi, maka pelaku usaha tidak memerlukan proses penyelidikan yang memakan waktu dan biaya yang lebih lama. Tidak semua pendapat memerlukan pendapat dari KPPU.

Post-merger notification memiliki kekurangan yakni potensi transaksi dapat dibatalkan oleh KPPU, potensi transaksi dikenai denda oleh KPPU. Selain itu, pelaku usaha memerlukan waktu tunggu yang lebih lama dalam ketidakpastian dan biaya transaksi yang lebih tinggi karena adanya biaya tunggu selama keputusan KPPU belum diberikan.

\section{Mengapa post-merger notification menimbulkan biaya transaksi tinggi dalam merger dan akuisisi di Indonesia?}

Dalam post-merger notification, memiliki 3 kemungkinan yakni:

1. Disetujui

2. Dibatalkan

3. Diberikan sanksi 
Masing-masing opsi ini mengandung biaya yang harus ditanggung oleh pelaku usaha dijelaskan pada tabel 5.

Tabel 5. Pendapat KPPU Terhadap Transaksi Penggabungan,

Peleburan, dan Pengambilalihan

\begin{tabular}{|c|c|c|}
\hline No. & Keterangan & Biaya \\
\hline 1. & Disetujui & $\begin{array}{l}\text { 1. Waktu tunggu yang lama berdasarkan data pada tabel } 2 \text {, dimana } \\
\text { KPPU memberikan pendapat yang memerlukan waktu lama } \\
\text { 2. Opportunity cost yang tinggi selama menunggu. Pelaku usaha tidak } \\
\text { bisa melakukan aktivitas atau corporate action, jika KPPU belum } \\
\text { memberikan pendapat } \\
\text { 3. Biaya konsultan yang meningkat, dikarenakan diperlukan waktu } \\
\text { menunggu }\end{array}$ \\
\hline 2. & Dibatalkan & $\begin{array}{l}\text { 1. Pelaku usaha akan mengembalikan semua status hukum para pihak } \\
\text { jika transaksi dibatalkan. } \\
\text { 2. Biaya yang harus dikeluarkan maupun yang sudah dikeluarkan tidak } \\
\text { bisa dikembalikan. }\end{array}$ \\
\hline 3. & Diberikan sanksi & $\begin{array}{l}\text { 1. Biaya tambahan dikarenakan sanksi yang diberikan, terutama jika } \\
\text { diberikan sanksi denda, sehingga menjadi beban daripada pembeli } \\
\text { atau perusahaan target. }\end{array}$ \\
\hline
\end{tabular}

Sumber : Hasil Penelitian

Jika pendapat KPPU adalah disetujui, pelaku usaha memiliki biaya dan waktu tunggu yang dikeluarkan. Adanya opportunity cost yang mana, selama masa tunggu ini, pelaku usaha tidak boleh melakukan hal apapun termasuk corporate action atas pengambilalihan, penggabungan dan peleburan.

Jika pendapat KPPU adalah membatalkan, maka pelaku usaha harus mengeluarkan biaya untuk mengembalikan transaksi kembali ke posisi semula. Selain itu biaya-biaya yang telah dikeluarkan untuk membuat transaksi ini terjadi, menjadi sunk cost.

Jika pendapat KPPU adalah memberikan sanksi, maka pelaku usaha harus menanggung biaya transaksi yang tinggi. Biaya transaksi pengambilalhan, peleburan dan penggabungan menjadi lebih mahal.

Di samping itu, perusahaan asing memiliki operasi di Indonesia juga wajib menyampaikan pelaporan kepada KPPU, jika mereka melakukan penggabungan, peleburan dan pengambilalihan. Transaksi ini jika terjadi negara asal dan memiliki operasi di Indonesia, maka pelaku usaha asing juga wajib menyampaikan pelaporan ke KPPU.

Jika pelaporan dilakukan setelah transaksi maka hal ini akan berbeda dengan pelaporan di beberapa negara asal ${ }^{26}$ seperti Amerika, China, EU, dan juga ASEAN.

${ }^{26}$ International Chamber of Commerce. ICC Recommendations on Pre-Merger Notification Regimes, 2015, Retrieved from http://www.icc.nl/docman-standpunten/docman-commissies/docman-commisiesmededinging/69-icc-recommendations-on-pre-merger-notification-regimes/file 
Sehingga pelaporan di Indonesia menjadi berbeda sendiri dengan negara-negara lainnya, akan menimbulkan efek-efek.

Jika pre-merger notification diberlakukan, maka KPPU perlu menyiapkan:

1. Tenaga staff yang diperlukan untuk melakukan penyelidikan awal transaksi

2. Komitmen jangka waktu yang diperlukan untuk melakukan penyelidikan

3. Nilai minimum transaksi yang diperlukan melakukan pre-merger notification.

Atas dasar hal-hal di atas, KPPU bisa mengenakan biaya pelaporan yang harus dikeluarkan oleh pelapor atau pelaku usaha yang akan melakukan peleburan, penggabungan dan pengambilalihan. Dengan adanya biaya pelaporan ini, maka KPPU memiliki anggaran untuk melakukan penyelidikan.

Sehingga dapat disimpulkan bahwa pre-meger notification seharusnya tidak menjadi issue untuk kebocoran informasi. Karena hal ini telah dilakukan oleh otoritas lainnya. Di samping itu, dengan adanya regulator yang berbeda telah menyetujui dan mengetahui akan transaksi yang dijalankan, maka diperlukan koordinasi antara komisikomisi dalam pemerintahan. Seperti pengambilalihan bank oleh investor asing. Investor asing telah melaporkan hal ini kepada komisi anti monopoli di negara asal dan investor asing telah melaporkan kepada OJK. Akan tetapi, pelaporan kepada KPPU, dilakukan setelah transaksi dilakukan.

Tabel 6. Negara-Negara Yang Menganut Pre-Notification

\begin{tabular}{|l|c|l|}
\hline No. & Keterangan & \multicolumn{1}{c|}{ Negara } \\
\hline 1. & Pre-Notificaton & $\begin{array}{l}\text { European Union, China, Amerika Serikat, Negara-Negara ASEAN } \\
\text { kecuali Indonesia, Malaysia, Cambodia. }\end{array}$ \\
\hline
\end{tabular}

Dengan demikian hal yang terbaik dilakukan oleh pelaku usaha, melaporkan transaksi tersebut kepada semua regulator pada kesempatan yang sama, agar tidak terjadi perbedaan dan kebingungan antar pelaku usaha.

\section{PENUTUP}

Kegiatan Penggabungan, peleburan dan pengambilalihan perusahaan dilakukan untuk memaksimalkan nilai perusahaan kepada pemegang saham. Pelaksanaan penggabungan, peleburan dan pengambilalihan memiliki efek timbulnya posisi dominan dan praktek monopoli. Sehingga aktivitas penggabungan, peleburan dan pengambilalihan memerlukan persetujuan daripada komisi pemantau persaingan usaha. Akan tetapi, pengajuan persetujuan apakah dilakukan sebelum atau sesudah transaksi dilakukan. Berdasarkan Undang Undang No. 5 Tahun 1999, pelaporan dilakukan setelah transaksi dilakukan dengan kriteria-kriteria yang ditetapkan oleh Peraturan Pemerintah. Penelitian ini menyajikan efek-efek daripada pelaporan yang dilakukan setelah transaksi dilakukan. Penelitian ini mempergunakan pendekatan undang-undang, pendekatan kasus dan pendekatan komparatif. Pendekatan komparatif dengan membandingkan perundangundangan di beberapa negara lain. Penelitian ini menyimpulkan bahwa pemberitahuan kepada KPPU wajib dilakukan untuk transaksi dengan nilai tertentu agar tidak 
Dialogia luridica: Jurnal Hukum Bisnis dan Investasi

Volume 12 Nomor 1, November 2020

menimbulkan efek ketidakpastian dan biaya tinggi transaksi. Di samping itu, agar regulatsi di Indonesia memiliki kesamaan dengan transaksi sejenis di negara lain terutama ASEAN.

\section{DAFTAR PUSTAKA}

\section{Buku}

Menesh S. Patel, Merger Breakups, December 6, 2019.

Peter Mahmud Marzuki, Penelitian Hukum, Prenadamedia Group, Jakarta, 2019.

\section{Jurnal}

A. M. T. Anggraini, "Mandatory Post Merger Notification Under The Merger Review Regulation In Indonesia”. Celebrating Diversity: 10years of ASLI 10th Asian Law Institute Conference, 2013.

A.M. Tri Anggarini, dan Farid F. Nasution, "Pengendalian Merger Berdasarkan Hukum Persaingan (Merger Control Based on Competitiion Law)", Jurnal Legislasi Indonesia, Vol. 10 No. 2, 2013.

A. M. T. Anggraini, "Merger Control Based On Anti Monopoly Law in Indonesia: Comparison in Some Asean Member States". Forum Dosen Persaingan Usaha, 2017. https://doi.org/10.1017/CBO9781107415324.004

Buccirossi, P., Cervone, R., Riviera, C., dan Regime, I. M., "Optimal Pre-Merger Notification Thresholds: a Contribution To the Italian Debate". Italian Antitrust Review, 3, 2014, https://doi.org/10.12870/iar-11061.

Chongwoo, C., dan Shekhar, C. (2009). "Compulsory or Voluntary Pre-merger Notification? Theory and Some Evidence Compulsory or Voluntary Pre-merger Notification? Theory and Some Evidence". Munich Personal RePEc Archive, (13450), 39.

Fahamsyah Ermanto dan Suri Fadhillah Atika, "Post-Notification Arrangements in Merging Business Entities (Mergers) as an Effort to Prevent Unfair Business Competition”. Lentera Hukum, Vol. 6 Issue 2, 2019.

Farid Ibrahim Suhandi, "Kebijakan Pre-Merger Notification Badan Usaha Sebagai Penegakan Hukum di Era Revolusi Industri 4.0”, Lex Scientia Law Review, Vol. 3 No. 2, 2019.

Hottua Manalu, "Notifikasi Aksi Korporasi Sebagai Instrumen Hukum Pencegah Praktik Monopoli dan Persaingan Usaha Tidak Sehat", Undang: Jurnal Hukum, Vol 2 No.1, 2019, . DOI: 10.22437/ujh.2.1.33-67

Irina V. Kozlenkova, Stephen A. Samaha dan Robert W. Palmaties, "Resources-based Theory in Marketing", Journal of the Academy of Marketing Science, 2013. DOI: 10.1007/s11747-013-0336-7

Joseph Farrell dan Carl Shapiro, "Antitrust Evaluation of Horizontal Mergers: An Ecoomic Alternative to Market Definition", The B.E. Journal of Theoretical Economics, Vol. 10 No. 1, 2010, Article 9. 
Ping Deng dan Monica Yang, "Cross-Border Mergers and Acquisition by Emerging Market Firms: A Comparative Investigation”, International Business Review, Vol. 24 No. 1, 2015. http://dx.doi.org/10.1016/j.ibusrev.2014.07.005

Prisya Esterlina dan Nila Nuzula Firdausi, "Analisis Kinerja Keuangan Perusahaan Sebelum dan Sesudah Merger dan Akuisisi”, Jurnal Administrasi Bisnis (JAB), Vol. 47 No. 2, 2017.

Li, J., dan Hou, L, "The Compulsory Notification Mechanism under Merger Control in China: Evaluation and Reform”. SSRN Electronic Journal, 630, 2019. https://doi.org/10.2139/ssrn.3469361

Mardianto dan Natalis Christian Edi, "Dampak Merger dan Akuisisi Terhadap Kinerja Keuangan Perusahaan”, Jurnal Benefita, Vol. 3 No. 1, 2018.

Munawir Nasir dan Tiara Morina, "Analisis Perbandingan Kinerja Keuangan Pada Peruahaan Sebelum dan Sesudah Merger dan Akuisisi (Studi Perusahaan Yang Melakukan Merger dan Akuisisi Yang Terdaftar di BEI 2013-2015)", Jurnal Economic Resources, Vol. 1 No. 1, 2018.

Rekha Resmilia, Arief Tri Hardianto, danAgung Fajar Ilmiyono, "Pengaruh Merger dan Akuisisi Terhadap Kinerja Keuangan Perusahaan Manufaktur Go Public Yang Terdaftar di BEI Periode 2012-2014", Jurnal Onlne Mahasiswa (JOM) Bidang Akuntansi, Vol. 5 No. 5, 2018.

Suradiyanto dan Dinny Wirawan Pratiwie, “Analisis Yuridis Pengambialihan Saham PT. Prima Top Boga Oleh PT. Nippon Indosari Corpindo, Tbk Dari Perpektif Undang Undang Nomor 5 Tahun 1999 (Studi Kasus Putusan Komisi Pengawas Persaingan Usaha Nomor: 07/KPPU-M/2018)”, Jurnal Ilmiah Hukum, Vol. 11 No. 2, 2019.

Suwinto Johan, "Implementasi Strategi Bisnis dan Korporasi Melalui Merger dan Akuisisi”, Ultima Management, Vol. 3 No. 1, 2011.

Suwinto Johan, Hermanto Siregar, Perdana Wahyu Santoso, dan Tubagus Nur Ahmad Maulana, "Do Foreign Firms Bring Value to Emerging Country?", Journal of Technology Management, Vol. 11 No. 3, 2012.

Xavier Nugraha, Rizki Istighfariana Achmadi, Nina Ammelia Novita Sari, "Urgensi Notifikasi Pratransaksi 3P (Penggabungan, Peleburan, Pengambilalihan) Upaya Preventif Persaingan Usaha Tidak Sehat”, Legistatif, Vol. 2 No. 2, 2019.

\section{Peraturan dan Perundang-undangan}

Putusan Perkara Nomor 07/KPPU-M/2014. Komisi Pemantau Persaingan Usaha, Vol. 07, 2014. https://doi.org/10.1017/CBO9781107415324.004.

Putusan Perkara Nomor 01/KPPU-M/2014. Komisi Pemantau Persaingan Usaha, 01, 24, 2014.

Putusan Perkara No. 03/KPPU-M/2014., Komisi Pemantau Persaingan Usaha, 03, 36, 2014. https://doi.org/10.1017/CBO9781107415324.004.

Putusan Perkara No. 03/KPPU-M/2014., Komisi Pemantau Persaingan Usaha, 02, 44, 2014 
Putusan Perkara No. 08/KPPU-M/2012. Komisi Pemantau Persaingan Usaha, 08, 50, 2012. https://doi.org/10.1017/CBO9781107415324.004.

Putusan Perkara No. 09/KPPU-M/2012. Komisi Pemantau Persaingan Usaha, , 09, 36, 2012.

Undang Undang No. 5 Tahun 1999 tentang Monopoli dan Persaingan Usaha Tidak Sehat. Undang Undang No. 13 Tahun 2003 tentang Ketenagakerjaan.

Undang Undang No. 40 Tahun 2007 tentang Perseroan Terbatas.

\section{Sumber Lainnya}

EU Competition Commision Case No. Comp/M.2220. General Electric/Honeywell. Regulation (EEC) No. 4064/89 Merger Procedure

International Chamber of Commerce. ICC Recommendations on Pre-Merger Notification Regimes, 2015, Retrieved from http://www.icc.nl/docman-standpunten/docmancommissies/docman-commisies-mededinging/69-icc-recommendations-on-premerger-notification-regimes/file

International Chamber of Commerce. (2015). ICC Recommendations on Pre-Merger Notification Regimes. Retrieved from http://www.icc.nl/docmanstandpunten/docman-commissies/docman-commisies-mededinging/69-iccrecommendations-on-pre-merger-notification-regimes/file 